\title{
Analyzing Teachers' Strategies for Motivating Students in Classroom at Primary Level: Students' Perspectives
}

\author{
${ }^{\text {a }}$ Nusrat Nawaz Abbasi, ${ }^{\text {b }}$ Masood Ahmad, ${ }^{c}$ Muhammad Javed, ${ }^{\text {d }}$ Sabiha Iqbal \\ a Assistant Professor Department of Education, The Govt. Sadiq College Women University, Bahawalpur, Pakistan \\ Email: nusrat.nawaz@gscwu.edu.pk \\ ${ }^{\mathrm{b}}$ Assistant Professor, Department of Educational Training, The Islamia University of Bahawalpur, Pakistan \\ ${ }^{c}$ Associate Professor/Chairman Department of Language Education, The Islamia University of Bahawalpur, \\ Pakistan \\ Email: muhammad.javed@iub.edu.pk \\ d Assistant Professor, Department of Education, The Islamia University of Bahawalpur, Pakistan \\ Email: sabiha.iqbal@iub.edu.pk
}

\begin{tabular}{|c|c|}
\hline ARTICLE DETAILS & ABSTRACT \\
\hline History: & \multirow{10}{*}{$\begin{array}{l}\text { The study was designed to analyze the teachers' strategies for } \\
\text { motivating students in classroom. The objectives of the study were; to } \\
\text { find out the techniques of motivation for students learning achievement; } \\
\text { to explore the students' views about motivation; to evaluate the } \\
\text { students' views regarding teachers' teaching style; to find out gender } \\
\text { wise significance difference. The study was design for Bahawal Nagar } \\
\text { district, so Bahawal Nagar were the population of the study. Stratified } \\
\text { sampling technique was used to select sample. One hundred and thirty } \\
\text { two (132) students were selected from selected schools in which } 66 \\
\text { schools were male and } 66 \text { female. Self-constructed instrument on } 4 \text { point } \\
\text { Likert scale was used to collect data. The major findings of the study } \\
\text { were teachers motivate the students at primary level by adopting } \\
\text { different techniques and strategies. The teachers' behaviour, personality, } \\
\text { teaching methodology and school environment are also factors affecting } \\
\text { the students' learning process. Immediate appreciation, rewards, } \\
\text { punishment, reinforcement and encouragement play a vital role for } \\
\text { motivating the students. It was also found that female teachers were } \\
\text { used more motivational strategies to motivate the students in classroom } \\
\text { as compared to male teachers. }\end{array}$} \\
\hline & \\
\hline Available Online June 2021 & \\
\hline & \\
\hline & \\
\hline Primary School Teachers; Public & \\
\hline Schools; Motivational Strategies & \\
\hline JEL & \\
\hline$P_{36, I 21}$ & \\
\hline DOI: $10.47067 /$ real.v4i2.168 & \\
\hline
\end{tabular}

(C) 2021 The authors. Published by SPCRD Global Publishing. This is an open access article under the Creative Commons AttributionNonCommercial 4.0

Corresponding author's email address: nusrat.nawaz@gscwu.edu.pk

\section{Introduction}

Motivation is an inner energy which fastens the behavior or response of the individual. Few learners learn the similar subject-matter or commission more quickly than others, few of them find it interesting and rewarding than the other one; on the other hand enjoy it more and more than others (Aggarwal, 2005). At the same time learners are differ in the same situation in which they are ready to 
direct their willingness to achieve the objectives, due to the variation of motivational techniques. Majority of the motivational theorists undertake that motivation is involved in all the aspect which the learners perform either in school or elsewhere. Ames (1984) describe that generally, the chief question among the psychologists is either motivation is a primary or secondary factor to influence the behavior of the learners. Changes in behavior are better explained due to the perception, memory, cognitive development, emotion, personality is unique concept to increase motivation. Motivation is divided into different types; majorly it is divided into following ways.

Corno (1985) illustrates that intrinsic motivation is the natural tendency to seek out and conquer challenges as we pursue personal interests and exercise capabilities. We do not have need incentives or punishment, when we are intrinsically motivated because the provided activity is itself a reward. The motivation which comes from the outside is refer to extrinsic motivation. Reilly (2005) describes that motivational factors are external or outside; it may be reward, punishment, money and grade. These rewards give pleasure and satisfaction to the students to perform a specific task.

Dweck (1983) describes the four different stages in the development of motivation. Every stage has its own characteristic and type of reinforcement. At first stage, it is said that reinforcement is bodily and concrete. Psychological need and satisfaction is direct at this level. At second stage, it is said that reinforcement is concrete but externally in involve tangible reward i-e prizes, physical give reward. The third stage includes intangible but external reinforcement similar to being well-thought, esteem of others, etc. The final stage includes energetic apprehension for reinforcement, self-actualization and internal reinforces, such as self-respect. All the teachers are necessary to keep in mind all the stages of motivational development during the teaching learning process. If the teachers follow these stages, the quality of teaching and learning can be improved (Mangal, 2006).

Woolfolk (2004) define that physical conditions of the classroom should be kept in mind by the teachers. No distracting factors should be around the classroom while teaching learning process. Some undesirable scenes often divert the attention of the students in classroom such as noise, strong light and loud horn of the buses. Temperature is also a disturbing factor while teaching. Boredom is created by monotony. The classrooms should be ventilated and discerningly ornamented. Flowery plants must be in the school premises. Adequately cleanliness should be harassed. Rashid (2008) illustrates that behaviour of the small children must be directed by their impulses. Hoarding, curiosity, self-assertion, construction, pugnacity are few of their most powerful desiccates, these activities provide the basis of all types of their actions. Little kids are passionately involved in nature. They feel pleasure to do many tasks frequently. Each strange and new attract there attention. A well-organized teacher will inspire the desire of inquisitiveness. He will continuously begin lesson by showing the interest. In the same way, children like to formulate the things. It is necessary for teacher to encourage children to study and to create new things.

Wlodkowski (1978) describes, theory of the behavior describes that the individual should avoid the painful experiences which give satisfaction and pleasant experience. This theory may directly be implemented in classroom teaching and learning process. The teacher should give satisfying and pleasant experiences to the students so that the students will be motivated for further learning. Teacher should teach the student that there should be an objective to be reached in each lesson. In this way the students can attempt to continue their struggle to complete the particular tasks. The objective should be clear for every student. To share successful experiences, students can motivate to continue his academic activities. The teacher should make a school work to the form i-e curricular and co-curricular; in this way every student have a chance to make experiences on his own efforts. Teachers should 
confirm frequent and regular experience throughout all phased of learning to success or reenforcement, particularly earlier period will be very difficult. Arrange competition program is a very good activity for institutions. Competition at individual level is not so effective because in this type of situation some student may be threatening. Competition between groups makes it possible to spread the share of success or failure. Competition program gives motivation to students and as well as it give social awareness to learners when they find belonging needs and satisfaction of their acceptance (Hamachek, 1990).

It is also very effective form of motivation that students have knowledge of their progress, of how well they are moving towards their objective. Good (2004) illustrates that moving towards the objective helps them to put greater efforts to achieve the objectives. Individual progress charts keeps the child involved in learning activity and also inform a child how he is doing well or not. Through programmed learning, children are said to learn healthier because students can get immediate feedback of failure and success. To motivate students on the way to self-actualization makes students search for the new things and ideas and the other different aspects like excursions, field trips, dramatics, literary activities and sports, etc. These activities can satisfy the students' needs for self-actualization by giving them an opportunity. But students' safety requirements need that they should know earlier when and how the innovative practices will be provided. All the children are different abilities, interests and competences. According to Dweck (1998) all the lessons cannot motivate all the children at the same time. So it is the responsibility of the teachers to know the individual interest of the students and their abilities to motivate them. Students can be influenced by the teaching skills of the teachers. It is very hard for an individual to give an exact number of teaching skills which are involved to motivate the students in classrooms.

Deci (2000) explains that teacher should know that what he is going to teach and whom he is teaching, if the teacher is not doing so and interested in his work he cannot motivate his class. It is said that a teacher who is teaching the same subject for a long time. It may be said that a teacher who has been teaching the same subjects to the same classes for a long time can tends to lose the interest in his subject but this is not the reason of disinterest, the subject-matter can be the similar but the students cannot be same, even the subject-matter is developing and changing. Additionally, experience teacher can discover new methods and approaches and of teaching-learning process even the same subjectmatters. Brophy (2003) describes that even though motivation is one of the major responsibilities of instructing the students, it is the responsibility of the both instructor's and students. The classroom, subject lesson, atmosphere, the capability of the teachers, the personality of the teacher and the student all affect a student's motivation. The subsequent practices will support you in developing motivational approaches to use when teaching. Lesson plan keeps the motivational strategies, if the lesson is interesting it create interest and motivation among students; if not interesting it will cause boredom, restless and involvement. Quality of the instruction and teaching can be affected by the low response of the students. In this way you can lose enthusiasm and confidence in class, on the other hand you may cause the negative effect on students' motivation. To create interest in classroom, teacher should use variety of teaching material in classroom while instructing.

Instructional goals come from directly the learning objectives. Ames (2000) illustrate that all the objectives you are presenting should in each block of instruction, in this way students will easily know that after the teaching session what they are expecting to him. Students frequently need response when they are struggling to achieve the goals. The teacher can give feedback orally or in written form, but be sure you give acknowledgment for appropriate student achievement and 
behavior. Teacher should be sure to point out student mistakes and errors and these errors and mistakes how may correct. Appreciating the excellent performance and to point out those areas which need improvement contribute a lot in teaching learning process. If students put question, give them a detail feedback clearly related to educational objectives. Students' feeling of success and failure depends on the feedback given by the teachers. Teachers should always comment favorably on successful performance of the students. Woolfolk (2004) describes that teacher should be openly contribute and view point about students' performance. Students learn numerous experiences to the learning environment. Teacher should use these experiences to stimulate the interest and motivation of the students. Teachers can take advantage of on intrinsic motivation by developing academic activities in which students can willing engage because students are interested in the content and feel pleasure in assignment. These opportunities limited by some features characteristic in the environment of schooling obligatory attendance, outwardly arranged curriculum, public monitoring, and grading of performance. Additional, students vary in what they enjoy and find interest. Therefore, teachers can arrange activities that integrate elements that most students will find re-rewarding.

Adkins, Payne \& Ballif, (2006) define that when the students accomplish all the activities related to the curriculum with full interest and devotion, it is said that curriculum objectives are achieved. Once giving applications or examples of concepts are being taught, involve person, trends, or actions prominent in the newscast or in the childhood culture. Make sure about all the activities that either these are related to content, media or nature of response is new for students, and different from recently what they have been doing. Do not give the routine lesson and assignment to students become the daily grind? Butler and Nisan, (2003) illustrates that when students left completely on their own and make poor decisions provide them with a menu of selections or involve them to get their choices accepted earlier going ahead. Majority of the students desire activities that permit them to answer actively by interacting with the teacher or with one another, operating materials, or by doing somewhat other than just reading and listening. Give opportunities to students to take interest in role-playing simulations, educational games, creative applications and experiments of what is being learned. After a deep study of the literature and already conducted study, the researcher find the gap in this area and decide to conduct study, so the researcher tried to analyze the teachers' strategies to motivate students in classroom.

The study will be very significant for teachers and students. Students will be furnished at grass root level. The study will provide a guideline for teachers to motivate their students in classrooms. The teacher will be able to provide proper guidance and counseling to students. In this way, the study will give a chance to teachers to improve their teaching skills and strategies in classrooms. This study will be helpful for teachers to diagnose learning deficiencies and problems of students. It may be helpful in reviewing and raising instructional techniques and strategies.

Objectives of the Study are:

- To explore the techniques of motivation during teaching learning process.

- To analyze the students views about motivation.

- To evaluate the students views regarding teachers' teaching style.

- To find out the significant difference of male and female teachers.

\section{Research Methodology}

The study was designed to analyze the teachers' strategies to motivate students in classroom at primary level. The topic is related to current phenomena, so the researcher used descriptive method of research to analyze teaching strategies. Descriptive method of research is very appropriate for current 
studies; so it was decided that survey method will be effective for data collection from the respondents. Self-constructed questionnaire was used in this study,. Questionnaire was prepared on four point likert scale having 41 items related to teachers' motivational strategies. Population of the study was all the primary schools of boys and girls of district Bahawal Nagar. Stratified sampling technique was used to select sample from target population. In this was 132 primary schools of Bahawal Nagar district were selected. Sixty six primary schools of boys and 66 primary schools of girls were selected as a sample of the study. To analysis the data mathematical techniques i-e percentage and t-test of independent variable was used to finalize the conclusions.

\section{Data Analysis}

The study was designed to analysis the teachers' strategies to motivate students in classroom at primary level. Data were analyzed in the following tables and draw the results:

Table 1: Students' responses about teachers' strategies for motivating students in classroom at primary level

\begin{tabular}{|c|c|c|c|c|c|}
\hline \multirow{2}{*}{$\begin{array}{l}\text { Sr. } \\
\text { No }\end{array}$} & \multirow[t]{2}{*}{ Statements } & \multicolumn{4}{|c|}{ Responses } \\
\hline & & SA & A & D & SD \\
\hline 1. & Teachers appreciate on your good performance. & $\begin{array}{c}95 \\
71.96 \% \\
\end{array}$ & $\begin{array}{c}36 \\
27.27 \% \\
\end{array}$ & $\begin{array}{c}1 \\
0.75 \% \\
\end{array}$ & $\begin{array}{c}\mathrm{O} \\
\mathrm{O} \% \\
\end{array}$ \\
\hline 2. & $\begin{array}{l}\begin{array}{l}\text { Teachers give rewards on your good } \\
\text { performance. }\end{array} \\
\end{array}$ & $\begin{array}{c}72 \\
54 \cdot 54 \% \\
\end{array}$ & $\begin{array}{c}36 \\
27.27 \% \\
\end{array}$ & $\begin{array}{r}17 \\
12.88 \% \\
\end{array}$ & $\begin{array}{c}7 \\
5 \cdot 30 \% \\
\end{array}$ \\
\hline 3. & Do you feel happy, when you get prize? & $\begin{array}{c}105 \\
79.55 \% \\
\end{array}$ & $\begin{array}{c}26 \\
19.70 \% \\
\end{array}$ & $\begin{array}{c}1 \\
0.75 \% \\
\end{array}$ & $\begin{array}{c}\mathrm{O} \\
\mathrm{O} \% \\
\end{array}$ \\
\hline 4 . & Teachers punish on your poor performance. & $\begin{array}{c}25 \\
19 \cdot 94 \% \\
\end{array}$ & $\begin{array}{c}47 \\
35.61 \% \\
\end{array}$ & $\begin{array}{c}30 \\
22.73 \% \\
\end{array}$ & $\begin{array}{c}30 \\
22.73 \% \\
\end{array}$ \\
\hline 5. & $\begin{array}{l}\text { Teachers motivate you on your poor } \\
\text { performance. }\end{array}$ & $\begin{array}{c}94 \\
71.21 \% \\
\end{array}$ & $\begin{array}{c}22 \\
16.67 \% \\
\end{array}$ & $\begin{array}{c}3 \\
2.27 \% \\
\end{array}$ & $\begin{array}{c}13 \\
9.85 \% \\
\end{array}$ \\
\hline 6. & $\begin{array}{l}\text { Teachers try to find the reasons of your poor } \\
\text { performance. }\end{array}$ & $\begin{array}{c}93 \\
70.45 \%\end{array}$ & $\begin{array}{c}33 \\
25 \%\end{array}$ & $\begin{array}{c}4 \\
3.03 \\
\end{array}$ & $\begin{array}{c}2 \\
1.52 \% \\
\end{array}$ \\
\hline 7. & $\begin{array}{l}\text { Teachers create friendly environment during } \\
\text { teaching. }\end{array}$ & $\begin{array}{c}81 \\
61.36 \% \\
\end{array}$ & $\begin{array}{c}31 \\
34 \cdot 48 \\
\end{array}$ & $\begin{array}{c}11 \\
8.33 \% \\
\end{array}$ & $\begin{array}{c}9 \\
6.82 \% \\
\end{array}$ \\
\hline 8. & Teachers provide curricular activities in the class. & $\begin{array}{c}74 \\
56.06 \%\end{array}$ & $\begin{array}{c}37 \\
28.03 \%\end{array}$ & $\begin{array}{c}4 \\
3.03 \%\end{array}$ & $\begin{array}{l}17 \\
12.88 \%\end{array}$ \\
\hline 9. & $\begin{array}{l}\text { Teachers conduct competition between students } \\
\text { to increase learning. }\end{array}$ & $\begin{array}{c}79 \\
59.85 \%\end{array}$ & $\begin{array}{c}47 \\
35.61 \%\end{array}$ & $\begin{array}{c}\mathrm{O} \\
\mathrm{O} \% \\
\end{array}$ & $\begin{array}{c}6 \\
4 \cdot 55 \%\end{array}$ \\
\hline 10. & Teachers make you active during teaching. & $\begin{array}{c}105 \\
79 \cdot 55 \%\end{array}$ & $\begin{array}{c}23 \\
17.42 \%\end{array}$ & $\begin{array}{c}3 \\
2.27 \% \\
\end{array}$ & $\begin{array}{c}1 \\
0.75 \%\end{array}$ \\
\hline 11. & $\begin{array}{l}\text { Teachers realize that you are an important } \\
\text { person of society. }\end{array}$ & $\begin{array}{c}98 \\
74.24 \% \\
\end{array}$ & $\begin{array}{c}30 \\
22.73 \% \\
\end{array}$ & $\begin{array}{c}3 \\
2.27 \% \\
\end{array}$ & $\begin{array}{c}1 \\
0.75 \% \\
\end{array}$ \\
\hline 12. & You feel interest in your studies. & $\begin{array}{c}98 \\
74.24 \%\end{array}$ & $\begin{array}{c}31 \\
23.48 \% \\
\end{array}$ & $\begin{array}{c}1 \\
0.75 \%\end{array}$ & $\begin{array}{c}2 \\
1.52 \% \\
\end{array}$ \\
\hline 13. & $\begin{array}{l}\text { You understand that, education is so important } \\
\text { for you. }\end{array}$ & $\begin{array}{c}106 \\
80.30 \%\end{array}$ & $\begin{array}{c}25 \\
18.94 \%\end{array}$ & $\begin{array}{c}1 \\
0.75 \%\end{array}$ & $\begin{array}{c}\mathrm{O} \\
\mathrm{O} \%\end{array}$ \\
\hline 14 . & Teachers behave proper outside the class. & $\begin{array}{c}79 \\
59.85 \% \\
\end{array}$ & $\begin{array}{c}40 \\
30.30 \% \\
\end{array}$ & $\begin{array}{c}8 \\
6.06 \% \\
\end{array}$ & $\begin{array}{c}5 \\
3.79 \% \\
\end{array}$ \\
\hline
\end{tabular}


Vol. 4, (2) 2021, 531-540

\begin{tabular}{|c|c|c|c|c|c|}
\hline 15 . & Teachers take care of your needs. & $\begin{array}{c}102 \\
77.27 \%\end{array}$ & $\begin{array}{c}22 \\
16.67 \%\end{array}$ & $\begin{array}{c}6 \\
4.55 \%\end{array}$ & $\begin{array}{c}2 \\
1.52 \%\end{array}$ \\
\hline 16. & You feel difficulties to get education. & $\begin{array}{c}17 \\
12.89 \% \\
\end{array}$ & $\begin{array}{c}36 \\
27.27 \% \\
\end{array}$ & $\begin{array}{c}29 \\
21.97 \% \\
\end{array}$ & $\begin{array}{c}50 \\
37.88 \% \\
\end{array}$ \\
\hline 17. & Teachers provide facilities in the class. & $\begin{array}{c}88 \\
66.67 \% \\
\end{array}$ & $\begin{array}{c}30 \\
22.73 \% \\
\end{array}$ & $\begin{array}{c}11 \\
8.33 \% \\
\end{array}$ & $\begin{array}{c}3 \\
2.27 \% \\
\end{array}$ \\
\hline 18. & Teachers help in your studies. & $\begin{array}{c}114 \\
86.36 \% \\
\end{array}$ & $\begin{array}{c}13 \\
9.85 \% \\
\end{array}$ & $\begin{array}{c}3 \\
2.27 \\
\end{array}$ & $\begin{array}{c}2 \\
1.51 \% \\
\end{array}$ \\
\hline 19. & Teachers try to find your problems. & $\begin{array}{c}85 \\
64 \cdot 39 \% \\
\end{array}$ & $\begin{array}{c}32 \\
24.24 \% \\
\end{array}$ & $\begin{array}{c}12 \\
9.09 \%\end{array}$ & $\begin{array}{c}3 \\
2.27 \% \\
\end{array}$ \\
\hline 20 & Teachers try to solve your problems. & $\begin{array}{c}93 \\
70.45 \% \\
\end{array}$ & $\begin{array}{c}26 \\
19.70 \\
\end{array}$ & $\begin{array}{c}10 \\
7.58 \% \\
\end{array}$ & $\begin{array}{c}3 \\
2.27 \% \\
\end{array}$ \\
\hline 21. & Teachers take care of your liking in your studies. & $\begin{array}{c}72 \\
54 \cdot 55 \% \\
\end{array}$ & $\begin{array}{c}36 \\
27.27 \% \\
\end{array}$ & $\begin{array}{c}14 \\
10.61 \% \\
\end{array}$ & $\begin{array}{c}10 \\
7.58 \% \\
\end{array}$ \\
\hline 22. & Teachers try to find your interest in your studies. & $\begin{array}{c}92 \\
69.70 \% \\
\end{array}$ & $\begin{array}{c}27 \\
24.45 \% \\
\end{array}$ & $\begin{array}{c}8 \\
6.06 \% \\
\end{array}$ & $\begin{array}{c}5 \\
3.79 \% \\
\end{array}$ \\
\hline 23. & $\begin{array}{l}\text { Teachers create interest in your lesson through } \\
\text { different methods. }\end{array}$ & $\begin{array}{c}97 \\
73.49 \% \\
\end{array}$ & $\begin{array}{c}26 \\
19.70 \% \\
\end{array}$ & $\begin{array}{c}3 \\
2.27 \% \\
\end{array}$ & $\begin{array}{c}6 \\
4.55 \% \\
\end{array}$ \\
\hline 24 . & Teachers provide games in the class. & $\begin{array}{c}30 \\
22.72 \% \\
\end{array}$ & $\begin{array}{c}51 \\
38.64 \% \\
\end{array}$ & $\begin{array}{c}23 \\
17.42 \% \\
\end{array}$ & $\begin{array}{c}28 \\
21.21 \% \\
\end{array}$ \\
\hline 25 . & $\begin{array}{l}\text { Teachers interact with your parents to get } \\
\text { information about you. }\end{array}$ & $\begin{array}{c}84 \\
63.63 \% \\
\end{array}$ & $\begin{array}{c}34 \\
25.80 \% \\
\end{array}$ & $\begin{array}{c}9 \\
6.81 \% \\
\end{array}$ & $\begin{array}{c}5 \\
3.79 \% \\
\end{array}$ \\
\hline 26. & Teachers encourage you for working. & $\begin{array}{c}88 \\
66.67 \% \\
\end{array}$ & $\begin{array}{c}40 \\
30.30 \% \\
\end{array}$ & $\begin{array}{c}3 \\
2.27 \% \\
\end{array}$ & $\begin{array}{c}1 \\
0.75 \% \\
\end{array}$ \\
\hline 27. & $\begin{array}{l}\text { Teachers use A.V aids in teaching for clearing the } \\
\text { concepts. }\end{array}$ & $\begin{array}{c}46 \\
34.84 \% \\
\end{array}$ & $\begin{array}{c}61 \\
46.21 \% \\
\end{array}$ & $\begin{array}{c}17 \\
12.90 \% \\
\end{array}$ & $\begin{array}{c}8 \\
6.06 \% \\
\end{array}$ \\
\hline 28. & $\begin{array}{l}\text { Teachers use innovation and project for creating } \\
\text { the interest. }\end{array}$ & $\begin{array}{c}41 \\
30.06 \% \\
\end{array}$ & $\begin{array}{c}66 \\
50 \% \\
\end{array}$ & $\begin{array}{c}14 \\
10.61 \% \\
\end{array}$ & $\begin{array}{c}11 \\
8.33 \% \\
\end{array}$ \\
\hline 29. & $\begin{array}{l}\text { Teachers provide opportunities for co-curricular } \\
\text { activities to enhance the confidence. }\end{array}$ & $\begin{array}{c}50 \\
37.88 \%\end{array}$ & $\begin{array}{c}57 \\
43.18 \% \\
\end{array}$ & $\begin{array}{c}11 \\
8.33 \%\end{array}$ & $\begin{array}{c}14 \\
10.61 \%\end{array}$ \\
\hline 30. & Teachers teach you in games. & $\begin{array}{c}54 \\
40.91 \%\end{array}$ & $\begin{array}{c}45 \\
34.09 \%\end{array}$ & $\begin{array}{c}21 \\
15 \cdot 91 \%\end{array}$ & $\begin{array}{c}12 \\
9 \cdot 91 \%\end{array}$ \\
\hline 31. & $\begin{array}{l}\text { Teachers used charts to create interest in the } \\
\text { class. }\end{array}$ & $\begin{array}{c}76 \\
57 \cdot 56 \%\end{array}$ & $\begin{array}{c}37 \\
28.03 \% \\
\end{array}$ & $\begin{array}{c}16 \\
12.12 \%\end{array}$ & $\begin{array}{c}3 \\
2.27 \% \\
\end{array}$ \\
\hline 32. & $\begin{array}{l}\text { Teachers use pictures to draw attention of the } \\
\text { students. }\end{array}$ & $\begin{array}{c}54 \\
40.91 \% \\
\end{array}$ & $\begin{array}{c}55 \\
41.67 \% \\
\end{array}$ & $\begin{array}{c}13 \\
9.85 \%\end{array}$ & $\begin{array}{c}10 \\
7 \cdot 58 \%\end{array}$ \\
\hline 33. & Teachers criticize on poor performance. & $\begin{array}{c}53 \\
40.15 \% \\
\end{array}$ & $\begin{array}{c}36 \\
27.27 \% \\
\end{array}$ & $\begin{array}{c}19 \\
14 \cdot 39 \% \\
\end{array}$ & $\begin{array}{c}24 \\
18.18 \% \\
\end{array}$ \\
\hline 34 . & Teachers threaten for making mistakes. & $\begin{array}{c}58 \\
43.92 \% \\
\end{array}$ & $\begin{array}{c}44 \\
33 \cdot 33 \% \\
\end{array}$ & $\begin{array}{c}18 \\
16.64 \% \\
\end{array}$ & $\begin{array}{c}12 \\
9.09 \% \\
\end{array}$ \\
\hline 35 . & Teachers reinforce for good behaviour. & $\begin{array}{c}82 \\
62.12 \% \\
\end{array}$ & $\begin{array}{c}36 \\
27.27 \% \\
\end{array}$ & $\begin{array}{c}10 \\
7 \cdot 58 \% \\
\end{array}$ & $\begin{array}{c}4 \\
3.03 \% \\
\end{array}$ \\
\hline 36. & Teachers show educational programs on T.V. & $\begin{array}{c}33 \\
25 \% \\
\end{array}$ & $\begin{array}{c}17 \\
12.88 \% \\
\end{array}$ & $\begin{array}{c}28 \\
21.21 \% \\
\end{array}$ & $\begin{array}{c}54 \\
40.91 \% \\
\end{array}$ \\
\hline 37. & Teachers teach with love and sympathy. & $\begin{array}{c}111 \\
84.09 \% \\
\end{array}$ & $\begin{array}{c}17 \\
12.88 \% \\
\end{array}$ & $\begin{array}{c}2 \\
1.51 \% \\
\end{array}$ & $\begin{array}{c}2 \\
1.51 \% \\
\end{array}$ \\
\hline 38. & Teachers stitch badge or sticker on continuous & 59 & 37 & 22 & 14 \\
\hline
\end{tabular}




\begin{tabular}{|l|l|c|c|c|c|}
\hline & good performance. & $44.70 \%$ & $28.03 \%$ & $16.67 \%$ & $10.60 \%$ \\
\hline 39. & Teachers make learning fun. & 61 & 54 & 12 & 5 \\
& & $46.21 \%$ & $40.92 \%$ & $9.09 \%$ & $3.29 \%$ \\
\hline
\end{tabular}

Table 1 shows the opinions of students about teachers' strategies to motivate students in classroom. Response rate shows that $99.23 \%$ respondents were agreed that the teachers appreciate students on their good performance; $81.81 \%$ agreed that teachers also give rewards on their good performance; $99.25 \%$ respondents were agreed that they feel happy, when they get prize; $55.55 \%$ students were agreed that the teachers punish on their poor performance; $87.88 \%$ respondents were that the teachers motivate students on their poor performance; 95.45\% agreed with this statement that the teachers try to find the reasons of their poor performance; 95.84\% respondents were agreed that teachers create friendly environment during teaching learning process; $84.09 \%$ students were agreed that the teachers provide curricular activities in the class. 95.46\% students were agreed that the teachers conduct competition between students to increase positive learning environment. 96.97\% respondents were agreed that the teachers make them active during teaching. 96.97\% students were agreed that the teachers realize that they are an important person of society. $97.72 \%$ respondents were agreed that they feel interest in their studies. 99.24\% students were agreed that they understand that, education is so important for them. 90.15\% respondents were of the opinion that teachers behave proper outside the class. 93.94\% students were of the view that the teachers take care of their needs. $59.85 \%$ students were disagreed that that they feel difficulties to get education. $89.4 \%$ students were of the opinion that teachers provide facilities in the class. $96.21 \%$ students were agreed that teachers help in their studies. $88.63 \%$ respondents were of the view that teachers try to find their problems. $90.15 \%$ students were of the opinion that teachers try to solve their problems. $81.82 \%$ students were agreed that the teachers take care of their liking in your studies. 94.15\% respondents were agreed that the teachers try to find their interest in their studies. 93.19\% students were agreed that teachers create interest in their lesson through different methods. $61.36 \%$ respondents were of the view that teachers provide games in the class. $89.43 \%$ students were of the opinion that teachers interact with their parents to get information about them. $96.97 \%$ respondents were agreed that teachers encourage them for working. 85.05\% students were agreed that teachers use A.V aids in teaching for clearing the concepts. 80.06\% respondents were of the view that teachers use innovation and project for creating the interest. $81.02 \%$ students were agreed that teachers provide opportunities for co-curricular activities to enhance the confidence. $75 \%$ respondents were in favour of that the teachers teach them with games. $85.59 \%$ respondents were agreed that teachers used charts to create interest in the class. $82.58 \%$ students were of the view that teachers use pictures to draw attention of the students. $67.42 \%$ respondents were of the opinion that teachers criticize on poor performance. $77.25 \%$ respondents were agreed that teachers threaten for making mistakes. 89.39\% students were of the view that teachers reinforce for good behaviour. 62.12\% respondents were disagreed that the teachers show educational programs on T.V. $96.97 \%$ students were agreed that teachers teach with love and sympathy. $72.73 \%$ respondents were agreed that teachers stitch badge or sticker on continuous good performance. 87.13\% students were agreed that teachers make learning funny. 
Table 2: Students' views about what do you do when teachers do not give prize on your good performance?

\begin{tabular}{|c|l|c|c|}
\hline \multirow{2}{*}{ Sr.No. } & \multirow{2}{*}{ Options } & \multicolumn{2}{|c|}{ Students Responses } \\
\cline { 2 - 3 } & & Frq. & \%age \\
\hline 1 & You become angry with teacher. & 0 & $0 \%$ \\
\hline 2 & You do not take interest in your studies. & 2 & $1.52 \%$ \\
\hline 3 & You work hard more for getting prize. & 127 & $96.21 \%$ \\
\hline 4 & You do not do anything. & 3 & $2.27 \%$ \\
\hline
\end{tabular}

Table 2 shows students' responses about what do you do when teachers do not give prize on your good performance? $96.21 \%$ students agreed that the students work hard more for getting prize when they do not able to get prize.

Table 3: Students' responses about the given of prize by the teachers in classrooms

\begin{tabular}{|c|l|c|c|}
\hline \multirow{2}{*}{ Sr. No. } & \multirow{2}{*}{ Options } & \multicolumn{2}{|c|}{ Students Response } \\
\cline { 3 - 4 } & & Frq. & \%age \\
\hline 1 & On your own choice. & 0 & O $\%$ \\
\hline 2 & In the opinion of students. & 8 & $6.06 \%$ \\
\hline 3 & Who do work well & 111 & $84.09 \%$ \\
\hline 4 & Give prize to intelligent students. & 13 & $9.86 \%$ \\
\hline
\end{tabular}

Table 3 indicates the views of students about the given of prize in classrooms. 84.09\% students were agreed that the teachers given prize to those students who do work well. It shows that teachers give prize on good performance of the students in classroom.

Table 4: Gender wise comparison about students' opinions about teachers' strategies to motivate students in classroom

\begin{tabular}{|c|c|c|c|c|c|c|}
\hline Variables & Gender & $\mathbf{N}$ & $\begin{array}{l}\text { Mean } \\
\text { Score }\end{array}$ & SD & t-value & p-value \\
\hline \multirow{2}{*}{$\begin{array}{c}\text { Teachers' strategies to motivate } \\
\text { students }\end{array}$} & Male & 66 & 3.12 & 0.74 & \multirow[b]{2}{*}{-9.96} & \multirow[b]{2}{*}{$0.00^{*}$} \\
\hline & Female & 66 & 3.97 & 0.49 & & \\
\hline
\end{tabular}

Table 3 indicates gender wise comparison of students' opinion about teacher's strategies to motivate students in classroom at primary level. Mean score of male (3.12) and female (3.97) shows that there was a significance difference about the use of motivational strategies $(t=-9.96, p<0.05)$. Mean score of female (3.97) was significantly higher than the male (3.12). It shows that female teachers were used more motivational strategies to motivate students in classroom to improve teaching learning process.

\section{Findings and Discussion}

The study attempted to analyze the teachers' strategies for motivating students in classroom at primary. The find of the study show that teachers motivate the students during teaching learning 
process by adopting different techniques and strategies. The teachers' behaviour, personality, teaching methodology and school environment are also factors affecting the students' learning process. Finding of the study show that majority of the teachers' behavior in class is friendly towards students, majority of the teachers having a good personality. Teachers' teaching methodology is suitable for students. They frequently used A.V. aid in classroom for the better understanding of the students. Similarly the A.V. aids, innovation, projects motivate the students. The finding show that majority of the teachers used innovative techniques and motivated strategies in classroom for the better grooming of the students. Immediate appreciation, rewards, punishment, reinforcement and encouragement play a vital role for motivating the students. Findings of the study show that teachers frequently motivate the students, occasionally given the reward to student and also appreciate the good work of the students. Findings also indicate that if the students did something wrong teachers punish him/her. Competition is a better technique to motivate the student in classroom. Competitions between students make the students' performance better. Knowing the students through interaction with parents, fellows and friends may be helpful for motivating the students. Butler and Nisan (2003) conducted study on effects of no feedback, task-related comments, and grade on intrinsic instruction and performance. The results of the study show that reward, incentive, apprecial, personality of the teachers, environment and methodology of the teachers are also a major role to motivate the students in classroom. Deci (1985) illustrates in his book intrinsic motivation and self-determination in human behavior that there are different ways to motivate the students in classroom. In which the major are teachers' personality, teacher's teaching methodology, school environment, friendly environment of the class, punishment and reward are the factors to motivate the students in classrooms.

Gender wise comparison was also calculated to evaluate the strategies to motivate the student at primary level. The findings of the study show that female teachers used more motivational strategies to motivate the students in classroom as compared to male teachers. It is general human nature that female teachers are more affiliated with child as compared to male, it may the factor that the female teachers. Lepper (2004) conducted study on intrinsic and extrinsic motivation in children. The findings of the study were also support the results of current study. Study concluded that female teachers were more affiliated with small kids that are the reason which motivate small kids more as compared the male teachers. Literature also supports the findings of this study. Dweck (1983) describes that female teachers have upper hand as compared to male teachers because female teachers are remain busy at home with children that' why children easily motivate from female teachers. Female teachers are softer as compared to male teachers.

\section{Conclusions}

It was concluded from the findings that the teachers motivate the students at primary level by adopting different techniques and strategies. The teachers' behaviour, personality, teaching methodology and school environment are also factors affecting the students' learning process. Similarly the A.V. aids, innovation, projects motivate the students. Immediate appreciation, rewards, punishment, reinforcement and encouragement play a vital role for motivating the students. Competitions between students make the students' performance better. Knowing the students through interaction with parents, fellows and friends may be helpful for motivating the students. It was also found that female teachers were used more motivational strategies to motivate the students in classroom as compared to male teachers.

\section{Recommendations}

After concentrating upon findings and conclusions I would like to put forward the following recommendations. 
- Teachers should appreciate on the students' good performance.

- Teachers should encourage the students on their poor performance through different techniques.

- Teachers should interact with student's parents to get information about them.

- Teachers should use innovation and project for creating interest and clearing the concepts.

- The teachers should provide opportunities for co-curricular activities in the school for motivating the students.

- The teachers should conduct activities in the classroom according to their lesson.

\section{References}

Adkins, D. C., Payne, F. D., \& Ballif, B. L. (2006). Motivation factor scores and response set scores for ten ethnic-culture groups of preschool children. American Educational Research Journal, 9, 557572.

Aggarwal, J.C. (2005). Essential of Education Psychology: New Delhi. Vikas Publishing House.

Ames, C. (2000). Research on Motivation in Education: The Classroom Milieu. Orlando: Academic Press.

Ames, C. (1984). Research on Motivation in Education: Students Motivation. Vol. I: New York: Academic Press.

Brophy, J. (2003). Conceptualizing Students Motivation: Educational Psychologist

Butler, R., \& Nisan, M. (2003). Effects of no feedback, task-related comments, and grade on intrinsic instruction and performance. Journal of Educational Psychology, 78, 210-216. (In Covington, 1998, p. 158).

Corno, L. (1985). The intrinsic Motivation to Learn in the classrooms: In Research on Motivation in Education. Vol. II: The Classroom Milieu, edited by C. Ames and R. Ames. Orlando: Academic Press.

Deci, E. (2000). Intrinsic Motivation and Self-Determination in Human Behavior: New York: Plenum.

Dweck, C. (1998). Achievement Motivation: In Handbook of Child Psychology. Edited by P. Mussen. New York: Wiley.

Gay, L.R. Educational Research. Competencies for analysis and application: Lahore: Mac-Million Publishing Company.

Good, T. (2004). Educational Psychology: A Realistic Approach. 3d Ed. New York: Longman.

Hamachek, D. (1990). Educational Psychology Reader: Toward the Improvement of Schooling. New York: Macmillan Publishing Company.

Lepper, M. R. (2004). Intrinsic and extrinsic motivation in children: Detrimental effects of superfluous social controls. In W. A Collins (Ed.) Minnesota symposia on child psychology (vol. 14, pp. 145214) Hillsdale, NJ: Erlbaum. In Covington, 1998, p. 144.

Mangal,S.K.(2006). Advance Educational Psychology: 2nd ed. Prentice Hall of India Pvt. Ltd.

Rashid, M. (2008). Educational Psychology: Islamabad. Allama Iqbal Open University Press.

Reilly, R. R. (2005). Educational Psychology: New York: Macmillan Publishing Co., Inc.

Reilly, R. R. (1983). Educational Psychology: New York: Macmillan Publishing Co., Inc.

Wlodkowski, R. J. (1978). Motivation and Teaching: A Practical Guide. Washington, D.C. National Education Association.

Woolfolk, A. (2004). Educational Psychology: 9th ed. Dorling Kinndersley (India) Pvt.Ltd. 